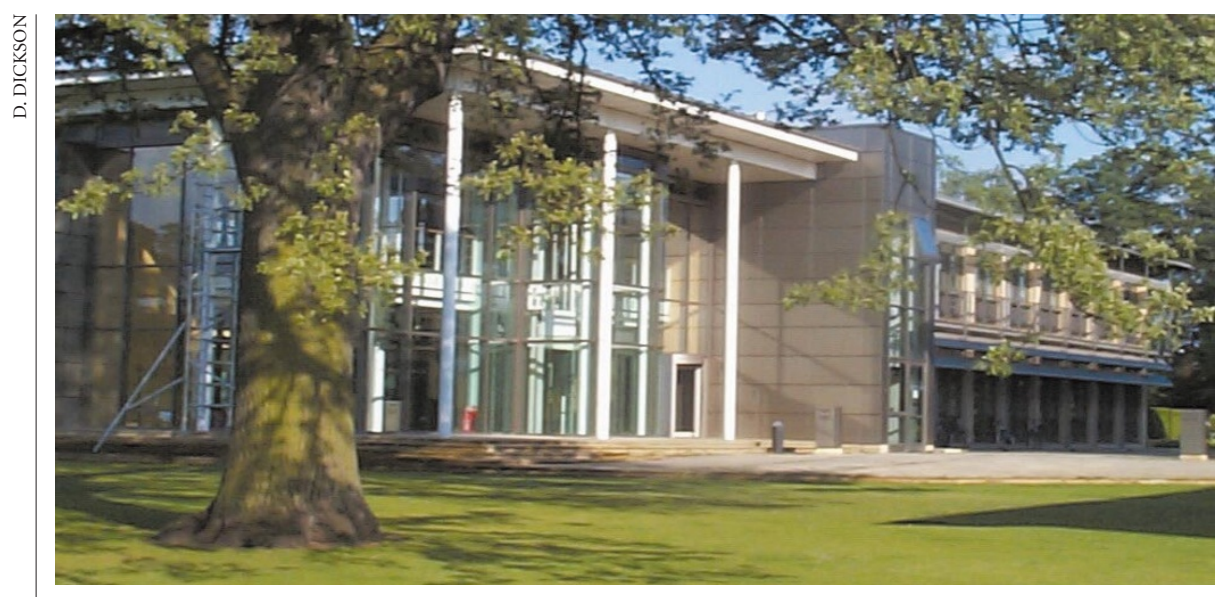

Hard up: the European Bioinformatics Institute outside Cambridge faces a precarious future.

\title{
European centres rebuffed in infrastructure funding bid
}

Quirin Schiermeier, Munich

Hopes that this week's meeting of Europe's research ministers might produce a quick political solution to the financial crisis threatening European life-sciences infrastructures appear to have been dashed.

The ministers have forced José Mariano Gago, Portugal's science minister and president of the European research council, to back down from a proposal to instruct the European Union (EU) to revise its existing funding rules, which exclude support of running costs for scientific facilities.

This is particularly disappointing for two such high-profile facilities: the European Bioinformatics Institute (EBI) at Hinxton Hall outside Cambridge and the European Mouse Mutant Archive (EMMA) at Monterotondo near Rome.

Although both were set up with support from the European Commission, funding from Brussels dried up last year as a result of a rule change in the EU's Fifth Framework Programme of Research (FP5). This now states that construction and operation of infrastructure in the life sciences are excluded from funding (see Nature 402, 4; 1999).

Both institutions are being kept alive by rescue funds, from the Italian research council for EMMA, and the European Molecular Biology Laboratory for the EBI. Long-term security is lacking, even though Gago asked European research commissioner Philippe Busquin in spring to make funding available to the facilities (see Nature 404, 217; 2000).

Gago also prepared a draft resolution to be presented to his fellow research ministers. But the initial draft, under which EMMA and EBI would have been re-eligible for funding under FP5, has been toned down significantly after member states expressed reservations. The revised draft merely "invites" the European Commission "to find a mechanism... enabling the Community to find a solution" to the problems of funding EMMA and EBI.

Even so, several EU member states - as well as the commission itself — still want all reference to EMMA and EBI to be omitted from the resolution. They suggest that infrastructure funding should be addressed in the 6th Framework Programme, for which discussions start in September.

A commission official points out that the work programme in FP5's 'Quality of Life' Special Programme was modified in November by restricting the clause excluding infrastructure funding to "routine operations". This excludes costs for computation, or for freezing and storage of mouse embryos.

Busquin says the results of the last call for proposals should be monitored to assess the impact of the modified exclusion clause before the commission considers further modifications. But Gago says European scientists would then be "hostage to bureaucracy".

Meanwhile, scientists at EMMA and EBI remain in a state of uncertainty. "We are still in a position of serious crisis," says Graham Cameron, co-head of the EBI. The EBI's largest task, according to Cameron, is the setting up of 'ArrayExpress', a public-domain repository for microarray gene-sequence expression data, which the EBI is pursuing with the help of industry while still seeking long-term government support.

EBI scientists have applied for funding from FP5 for projects worth 30 million euros (US\$29 million), of which only 1.5 million euros has so far been granted. EMMA gave up applying for FP5 money after its 1999 applications were turned down.

Infrastructure funding is a priority issue for the proposed 'European Research Area', a new initiative from Busquin. Options will be discussed in September at a high-level EU conference in Strasbourg.
Spanish postgrads push for better employment rights

Xavier Bosch, Barcelona

Postgraduate students in Spain have set up a nationwide organization in an attempt to improve their working conditions.

Known as the 'Precarious National Federation' - to reflect the situation in which the students see themselves - the new organization wants to see the current system of monthly student grants replaced by 'training contracts' that last for the whole length of the students' studies. The federation also wants all postgraduates to be given the status of 'research personnel in training'.

The creation of the federation reflects widespread dissatisfaction among students over their employment situation. Manuel Pérez-Mendoza, president of the federation and a research chemist at the University of Granada, says most postgraduates in Spain have no employment rights, such as affiliation to the social security system or health benefits.

Elisenda Vendrell, co-founder of the federation and a biologist at the Cancer Research Institute in Barcelona, argues that the work of postgraduate students "is seriously undervalued in the labour market".

She points out that even though the students spend a long time doing grantsupported research, as well as teaching, their work is not properly recognized. "For example, we have no representation in the governing bodies of public research institutions," she says.

Researchers in the federation have been making their case to senior university officials and those responsible for science in the main political parties. They also intend to negotiate directly with the Ministry of Education and Culture and the recently launched Ministry of Science and Technology.

The postgraduates have received support from some senior researchers. "Governments tend to adopt a rather cynical attitude towards young researchers, because they know that their eagerness to do research can lead them to accepting working conditions which would be unacceptable at a comparable level in other fields of employment," says John Beckman, research professor at the Higher Council of Scientific Research's Astrophysics Institute of the Canary Islands. "This situation is accentuated in Spain because of the rigidity of its administrative system". 